Journal of Business Studies - JBS Vol.13 Issue.1, May 2017

\title{
THE MEDIATING ROLE OF WORKPLACE INTERPERSONAL MISTREATMENT: AN EMPIRICAL INVESTIGATION OF BANKING SECTOR OF PAKISTAN
}

\author{
Naveed Iqbal Chaudhry \\ Department of Business Administration, University of the Punjab, Gujranwala, Pakistan \\ Hakim Ali Mahesar (Corresponding Author) \\ Assistant Professor, Institute of CommerceUniversity of Sindh, Jamshoro \\ Saima Kamran Pathan \\ Institute of Business Administration, University of Sindh, Jamshoro \\ Amina Arshad \\ Department of Business Administration, University of the Punjab, Gujranwala, Pakistan \\ AsadMunir Butt \\ Department of Business Administration, University of the Punjab, Gujranwala, Pakistan
}

\begin{abstract}
The underlying motive for this research is to figure out the structure of predictors and outcome of workplace bullying and workplace incivility in the banking sector of Pakistan. This paper aims to contribute valuable information about workplace bullying and workplace incivility as mediators to the scholarly research. An explanatory research design was employed. The data was collected from 600 banking professionals through personally administered questionnaires. SPSS-21 and Amos-21 were employed to analyze the quantitative data. For the purpose of testing hypotheses, structural equation modeling technique was employed. The results of this study provide a proof of association between the role stressors and two very important types of workplace interpersonal mistreatment, the workplace bullying and workplace incivility. Additionally, it was found that workplace bullying and workplace incivility play a mediating role between role stressors and turnover intentions among banking employees of Pakistan. Furthermore, the results reveal that the banking employees having experienced bullying and incivility are very prone to form turnover inclination.
\end{abstract}

Keywords: Role Conflict, Role Ambiguity, Role Overload, Workplace Interpersonal Mistreatment, Workplace Bullying, Workplace Incivility, Turnover Intention

Jel Classification: O16, O15

*The material presented by the author does not necessarily portray the view point of the editors and the management of the Institute of Business \& Technology - IBT

1. Naveed Iqbal Chaudhry:naveed.iqbal@pugc.edu.pk

2. Hakim Ali Mahesar: hakim.mahesar@usindh.edu.pk

3. Saima Kamran Pathan: saima.pathan@usindh.edu.pk

4. Amina Arshad: amanwarriach26feb@gmail.com

5. AsadMunir Butt: asad.butt35@gmail.com

CIBT-JBS is published by the Institute of Business \& Technology - IBT

Main Ibrahim Hydri Road, Korangi Creek, Karachi-75190, Pakistan. 


\section{INTRODUCTION}

For a number of years, the researchers have mainly concentrated on Workplace Interpersonal Mistreatment(Bibi et al., 2013). Different researchers have studied workplace interpersonal mistreatment from dual perspectives, as an antecedent and as consequence variable (Bruursema, 2005). Workplace interpersonal mistreatment is detrimental at both organizational levels as well as at individual level. It lowers the workers self-respect on one hand and on the other hand, it damages the organizational environment(Einarsen et al., 2003). Among several types of workplace interpersonal mistreatment, in recent decades, bullying has become a counterproductive phenomenon (Mata, 2012). According to a research conducted in Scandinavia, workplace bullying is a severe problem being faced at workplaces and according to a wild guess, 5\% of working population is experiencing bullying at workplace(Einarsen et al., 1994).

In Pakistani context the banking professionals facing workplace incivility tend to leave their jobs. A study conducted in Pakistan revealed that workplace incivility and interpersonal conflict together with organizational cynicism, may increase the probability of turnover intentions among banking employees (Ayyub et al., 2013).So far as the prevalence of workplace incivility in Pakistan is concerned, the employees from Pakistani organizations are experiencing this treatment and the findings are compatible with former studies like Cortina et al. (2001). Additionally, it has also been established that there is a need to further explore this phenomenon in Pakistani context(Milam, 2013).

Numerous studies have suggested that role stressors are significant predictors ofbullying at workplace(Baillien et al., 2011) and incivility (Pearson et al., 2000) at workplaces and ultimately these behaviors lead to forming quitting intentions. This research contributes to the global literature by identifying the role related causes and individual level consequences of bullying and incivility in banking sector of Pakistan. Moreover, the mediating role of bullying and incivility has also been tested in this study.

\section{LITERATURE REVIEW}

\subsection{Workplace Bullying}

Workplace bullying may be referred to as "all those repeated actions and practices that are directed to one or more workers, which are unwanted by the victim, which may be done deliberately or unconsciously, but clearly cause humiliation, offence, and distress, and that may interfere with job performance and/or cause an unpleasant working environment" (Einarsen, 1999). Organizational environment plays a vital role to promote or encourage workplace bullying. When the environment is characterized by chaos, unpredictability, lack of job security, role conflict, stress and strain, the workers would obviously compliant for being bullied (Lawrence, 2001). Role conflict and role ambiguity are organizational factors that contribute towards bullying at work. In a Norwegian research carried out by Einarsen et al. (1994), it was reported that unclear and unpredictable working conditions may cause bullying at work thus showing role conflict and ambiguity, strong predictors of workplace intimidation. Exposure to higher amounts of workloads also makes employees, an easy targets of workplace bullying (Hoel andSalin, 2003).

At workplaces, workplace bullying creates the feeling of degradation, demoralization and defenselessness among victims (Longo andSherman, 2007). Workplace bullying leads to an increase in absenteeism that is higher than normal rate of sick leave which is the first symbol of distress of workplace bullying (Kivimäki et al., 2000). Previous studies have attempted to 
unveil the relationship of workplace bullying with turnover intent and it has been found that there is positive association between bullying and turnover intent (Keashly and Jagatic, 2000).

\subsection{Workplace Incivility}

Workplace incivility may be defined as "low-intensity deviant behavior with ambiguous intent to harm the target, in violation of workplace norms for mutual respect. Uncivil behaviors are characteristically rude and discourteous, displaying a disregard for others"(Andersson andPearson, 1999). This definition reveals that the intentions of rudeness by the perpetrator are not clear. Actions perceived by the victim as rude and negative may have been unconsciously directed by the perpetrator (Naimon et al., 2013).Numerous probable causes of workplace incivility have been suggested including incongruously articulated annoyance, increased workload, stress, job insecurity, communication gap and poor work organization. Organizational change that leads to overwork, less resources, lack of job security and more challenging job description may also be a potential cause of workplace incivility (Johnson andIndvik, 2001). Employees may be confronted with workplace incivility when they are frustrated by stressful work demands(Dollard et al., 1939).

Workplace incivility demonstrates itself through its effects on both individuals and organizations. Workplace incivility causes a decrease in various performance related behaviors like productivity, creativity, performance, motivation and helping behavior (Pearson andPorath, 2005). Workplace incivility doesn't only make the environment within the organization unpleasant but it also affect the bottom line of the company very badly. In absence of workplace civility, there would be conflicts in work relations. Organizational environment constituting rudeness and uncivil behaviors would lead employees to be depressed and consequently there would be an increase in aggressive behaviors, turnover, loss of customers and lower productivity (Kamp and Brooks, 1991).

\subsection{Role Conflict}

"Role conflict is defined in terms of the dimensions of congruency and noncongruency or compatibility incompatibility in the requirements of the role, where congruency or compatibility is judged relative to a set of standards or conditions which impinge upon role performance"(Rizzo et al., 1970a). Role conflict results from violating two classical principles that are the principle of chain of command and unity of command and direction. Principle of chain of command states that the organizations are arranged in a hierarchical relationship where the flow of authority is clearly and unambiguously from upper level to lower level. Principle of unity of command and direction states that a worker should be assigned an activity from single authority and the one leader and one action plan should be there. The purpose of this principle is that an employee could be protected against incompatible demands. So role theory suggests that when the expectations from an employee are conflicting, the employee will feel dissatisfied with his job and will perform less effectively (Rizzo et al., 1970a).

The evidence based consequences of role conflict are being discontentand frustration with job. Some other organizational factors have also been correlated with role conflict which include dissatisfactory team or group relations (French andCaplan, 1972). Previous studies have recognized role conflict as being related with perceived workplace interpersonal mistreatment (Skogstada et al., 2007).

H1: Role Conflict has a positive relationship with Workplace Bullying.

H2: Role Conflict has a positive relationship with Workplace Incivility. 


\subsection{Role Ambiguity}

Role ambiguity was first time taken into consideration by Kahn et al, 1964 along with role conflict. Role ambiguity may be regarded as the degree to which "clear information is lacking regarding (a) the expectations associated with a role, (b) methods for fulfilling role expectations, and/or (c) the consequences of role performance" (Graen, 1976).Stress resulting from role conflict and role ambiguity may be well understood as a shape of cognitive dissonance which is postulated to generate tension (Futrelland Parasuraman, 1981). In early literature, the association of role conflict and role ambiguity was found significant predictors of job dissatisfaction (e.g. Coldwell, 1979).

There is a difference in consequences of role ambiguity among professions. As reported earlier that role ambiguity is linked with job dissatisfaction but various studies showed no relationship between these two factors. For instance studies conducted on nurses (Brief and Aldag, 1976), school teachers (Tosi and Tosi, 1970)and operational employees (Ivancevich and Donnelly, 1974) reported no significant association among role ambiguity and job dissatisfaction.The employees bearing role ambiguity react to the situation with anxiety, physical symptom, lower self-respect, a sense of useless reduced organizational commitment and job involvement (Brief andAldag, 1976). Role ambiguity is also positively correlated with turnover propensity (Lyons, 1971).

H3: Role Ambiguity has a positive relationship with Workplace Bullying. H4: Role Ambiguity has a positive relationship with Workplace Incivility.

\subsection{Role overload}

Role overload refers to "the situation where the expectations from an employee exceed the time available and his abilities" (Rizzo et al., 1970b). Role overload and role ambiguity have been recognized as a major causes of job related tension and stress (French et al., 1982). People with ambiguous and conflicting roles and have workload more than their capacity definitely experience fatigue, negative emotions and tension. Several studies have been carried out to check the relationship of role overload with propensity to leave and it is found that role overload increases the propensity to leave. Malik et al. (2013) found that role overload is associated with decreased productivity and increased propensity to leave.

Some researchers suggest that multiple role involvement lead to psychological distress because both time and energy are exhausted in multiple role involvement. But it must be taken into consideration that when a person having motivation and self-efficacy, takes role overload, as a challenge, then the role overload is positively related to higher performance (Boswell et al., 2004). A trend of downsizing due to economy has forced many workers to realize that they are being asked to fill the gap created due to downsizing. So, they frequently experience increased expectations and demands. This type of stress causes decreased commitment and satisfaction and increased turnover and burnout (Jones et al., 2007).

H5: Role Overload has a positive relationship with Workplace Bullying among banking professionals of Pakistan.

H6: Role Overload has a positive relationship with Workplace Incivility.

\subsection{Turnover Intention}

Turnover intention may be described as "an employee's cognizant and purposeful willingness to leave an organization"(Tett and Meyer, 1993). Turnover intention may be defined as "an attitudinal, decisional and behavioral process through which an employee, first thinks about leaving an organization, then forms intentions to leave the organization and 
searches for new job and finally quits the job". So this process literally leads to actual turnover (Sager et al., 1998). Many reasons for forming turnover intentions have been identified. A study conducted in Hongkong, confirmed that work role stressors (role conflict, role ambiguity and role overload) cause emotional exhaustion and low satisfaction which leads to form intentions to quit the job (Hang-Yue et al., 2005).

Employees report a significant turnover intentions and withdrawal when they experience workplace mistreatment (Glomb et al., 1997). Workplace bullying considerably affects the employees to form intentions to leave. Turnover intentions, though do not lead to actual turnover but in many studies significant correlations have been found between these two constructs specially where alternative opportunity for job is available (Parasuraman, 1982). Additionally, many organizational costs are associated with turnover (Waldman et al., 2004) in terms of cost associated with advertisement for new hiring, temporary employee cost, productivity cost and cost of selection. Most dreadfully suffering sector from turnover intentions problem is healthcare sector having highest turnover intention rates among other various sectors (Waldman et al., 2004).

H7: Role Conflict has a positive association with Turnover Intention.

H8: Role Ambiguity has a positive relationship with Turnover Intentions.

H9: Role Overload has a positive impact on Turnover Intentions.

H10: Workplace Bullying mediates the relationship between Role Conflict and Turnover Intention.

H11: Workplace Incivility mediates the relationship between Role Conflict and Turnover Intention.

H12: Workplace Bullying mediates the relationship between Role Ambiguity and Turnover Intention.

H13: Workplace Incivility mediates the relationship between Role Ambiguity and Turnover Intention.

H14: Workplace Bullying mediates the relationship between Role Overload and Turnover Intention.

H15: Workplace Incivility mediates the relationship between Role Overload and Turnover Intention.

H16: Workplace bullying has a positive relationship with propensity to leave.

H17: Workplace Incivility has a positive relationship on Turnover Intention.

\section{Theoretical Framework}

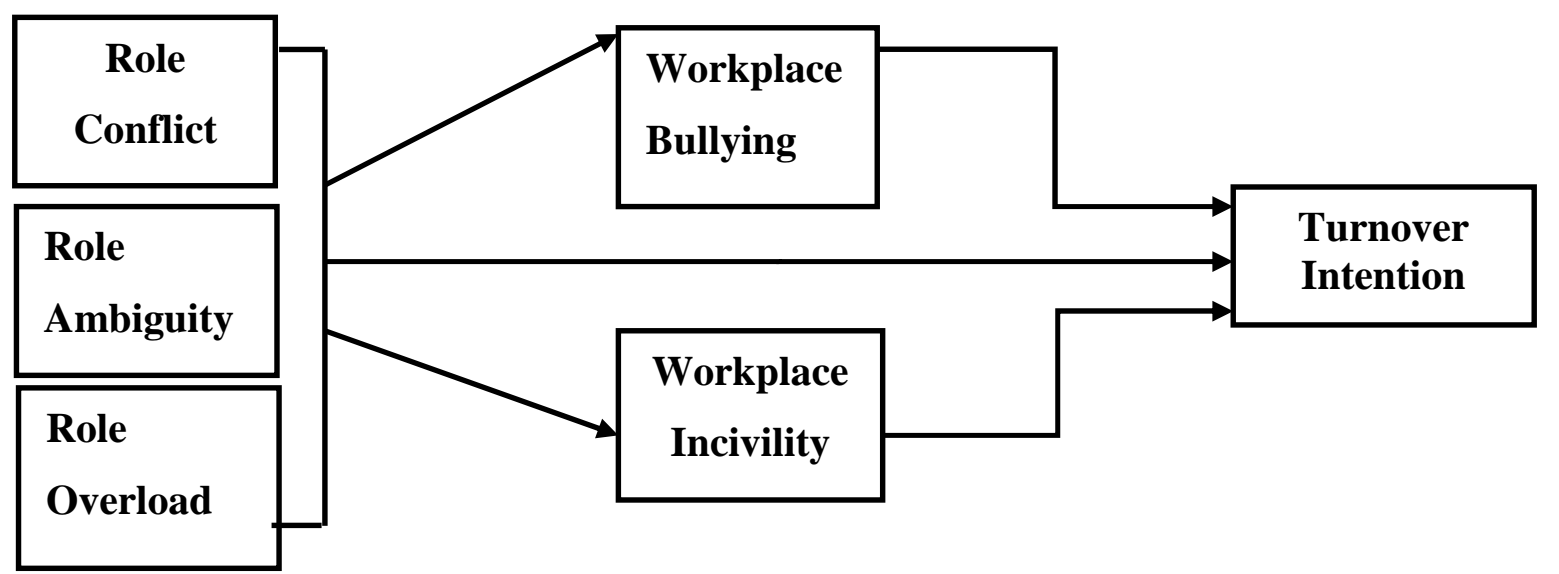




\section{RESEARCH METHODOLOGY}

\section{Participants and procedure}

The current study used a quantitative technique that is based on the questionnaire employed for gathering data to accomplish the objective of the study. A self-administered questionnaire was employedfor data collection using five point Likert scale.The population for the current study consists of banking professionals of all those banks that are operating in Pakistan. A total of 600 questionnaires were distributed out of which 502 completed questionnaires were returned back demonstrating a response rate of $83 \%$. There were 330 $(65.7 \%)$ male participants and $172(34.3 \%)$ female participants. The highest proportion of the sample was falling in the age group 25-29 consisting of 270 (53.8\%) respondents.

\section{Measures \\ Workplace bullying}

22items Negative Acts Questionnaire Revised (NAQ-R) (Einarsen and Hoel, 2001; Einarsen and Raknes, 1997) was employed to operationalize workplace bullying. These studies proved the internal consistency of the instrument. A five point Likert scale was used to record the responses with extreme points strongly disagree to strongly agree. Cronbach's Alpha for this research was 0.920 .

\section{Workplace incivility}

Seven items Workplace Incivility Scale (WIS) developed by (Cortina et al., 2001) was adopted to analyze workplace incivility using a five point Likert scale to record the responses .This scale has a high internal consistency having coefficient of alpha of 0.89 (Blau and Andersson, 2005). The coefficient of alpha in present research was 0.924 .

\section{Role conflict}

This study measures Role Conflict (RC) by eight items taken from (Rizzo et al., 1970a) using a five point Likert scale to record the responses. In a study conducted by (Schuler, 1977) estimated internal reliability (Cronbach's alpha) was0.82 for role conflict. The co-efficient of alpha for the current study was 0.891 .

\section{Role Ambiguity}

This paper measures Role Ambiguity (RA) by six items adopted from (Rizzo et al., 1970a) usinga five point Likert scale. This instrument has been widely employed inprevious literature and proved to be valid and reliable. The estimated internal reliability (Cronbach's alpha) was0.87 for role ambiguity (Schuler, 1977). The co-efficient of alpha for the current study was 0.885 .

\section{Role Overload}

This study employs the three itemsscale for measuring role overload was consistent with (Kahn et al., 1964). A five point Likert scale was used to record the responses having extreme points from strongly disagree to strongly agree. Black (1988) reported (Cronbach's alpha $=0.81)$ for the variable of Role Overload. The coefficient of alpha for the present study was 0.921 .

\section{Turnover intention}

Four items scale of turnover intention (TI) having high factor loading established by Kelloway et al.(1999) was used with five point Likert scale to examine the turnover intentions among employees. This construct had high internal consistency (Cronbach's alpha $=0.93$ ). In present study, the coefficient of alpha was 0.919 . 


\section{RESULTS AND DISCUSSION}

Out of 600 questionnaires, 502 complete questionnaires were received back. This study found that most of the respondents were male $(65.7 \%)$. Participants were mainly falling in the age group of 25-29 (53.8\%). So far as the marital status is concerned, majority of the respondents were single $(64.1 \%)$. Major portion of the respondents were belonging to private sector $(96 \%)$. With respect to qualification, the data indicates that great number of the respondents fall in the classification of masters with (49.4\%). Majority of the respondents (66.9\%) replied that their organization had less than 25 employees.A substantial part of the sample $(22.9 \%)$ responded that they had less than one year experience.

\subsection{Preliminary Analysis}

Preliminary analysis was done to make sure that assumptions for conducting structural equation modeling had been met. For this purpose, missing data, outliers screening and testing were done. Tests for calculating the mean, standard deviation,Cronbach's alpha (internal reliability) and correlational tests of the constructs constituting the model were also applied. The normality of constructs was tested by using graphical and statistical methods and found that data was normal. Means, Standard Deviations, Skewness and kurtosis statistics were calculated for 50 items constituting the 6 constructs included in the model and have been presented in the table 4.1.So far as the reliability of the constructs is concerned, Cronbach's Alpha for each construct was computed and has been presented in Table 4.1. Itis observed that the coefficient of alpha $(\alpha)$ is lying between 0.885 and 0.924 . According to Nunnally and Bernstein(1994) a scale must have a coefficient of Cronbach's alpha of at least 0.7. This guideline was used as benchmark. Cronbach's Alpha for the whole scale was also computed and it was 0.923 falling within the acceptable range. Correlations among the variables have also been given in the table 4.2.In order to assess the appropriateness of data for factor analysis, Kaiser Mayer-Olkin (KMO) measure and Bartlets test of spherecity were employed. According to Tabachnick et al.(2001), 0.6 or above values of KMO are mandatory for factor analysis. The KMO for the data was 0.791 falling within the acceptable range. A significant result of Bartlet's test of spherecity indicated that its value was appropriate for factor analysis. According to (Pallant, 2007) its value must be less than or equal to 0.5 and its value for the current study is 0.000 .

Table 4.1: Descriptive Statistics

\begin{tabular}{|l|l|l|l|l|l|}
\hline Name of Variable & $\begin{array}{l}\text { Mean } \\
\text { Statistic }\end{array}$ & $\begin{array}{l}\text { Std. Deviation } \\
\text { Statistic }\end{array}$ & $\begin{array}{l}\text { Skewness } \\
\text { Statistic }\end{array}$ & $\begin{array}{l}\text { Kurtosis } \\
\text { Statistic }\end{array}$ & $\begin{array}{l}\text { Coefficient } \\
\text { of }(\boldsymbol{\alpha})\end{array}$ \\
\hline Workplace Incivility & 4.0876 & .51047 & .543 & -.786 & 0.891 \\
\hline Workplace Bullying & 4.1154 & .63263 & -.377 & -.508 & 0.885 \\
\hline Role Conflict & 3.8730 & .37501 & .699 & -.126 & 0.921 \\
\hline Role Ambiguity & 4.2243 & .51474 & -.488 & -.085 & 0.920 \\
\hline Role Overload & 4.2067 & .48183 & -.121 & -.449 & 0.924 \\
\hline Turnover Intentions & 4.1346 & .62124 & -.347 & -.059 & 0.919 \\
\hline
\end{tabular}


Table 4.2: Correlations

\begin{tabular}{|l|l|l|l|l|l|l|}
\hline Variable Name & WI & WB & RC & RA & RO & TI \\
\hline Workplace Incivility & $\mathbf{1}$ & & & & & \\
\hline Workplace Bullying & $.647^{* *}$ & $\mathbf{1}$ & & & & \\
\hline Role Conflict & $.734^{* *}$ & $.521^{* *}$ & $\mathbf{1}$ & & & \\
\hline Role Ambiguity & $.607^{* *}$ & $.608^{* *}$ & $.621^{* *}$ & $\mathbf{1}$ & & \\
\hline Role Overload & $.489^{* *}$ & $.350^{* *}$ & $.488^{* *}$ & $.318^{* *}$ & $\mathbf{1}$ & \\
\hline Turnover Intentions & $.618^{* *}$ & $.529^{* *}$ & $.599^{* *}$ & $.466^{* *}$ & $.663^{* *}$ & $\mathbf{1}$ \\
\hline **. Correlation is significant at the 0.01 level (2-tailed). & & \\
\hline
\end{tabular}

\subsection{Structural Equation Modeling}

After proving the normality and reliability of data, Structural Equation Modeling was employed to check the theoretical model of current study. For this purpose IBM-AMOS 21 was employed using a two-step approach (Anderson and Gerbing 1988). The measurement model and theoretical structural model were tested separately using this two-step approach(Anderson and Gerbing, 1988). CFA was done first to analyze the conceptual model. CFA was done on all variables i.e. Role Conflict, Role Ambiguity, Role Overload, Workplace Bullying, Workplace Incivility and Turnover Intention.Model fit can be assessed through normed chi-square which is $\mathrm{x}^{2} / \mathrm{df}$. Kline, (2011)establishes that for a model fit to be good, the value of normed chi-square must be 3 or less than 3. While conducting CFA, for each variable, model fit was examined and it was found that with retained items of each construct, the model was at good fit for each construct.

\subsubsection{Measurement Model}

All of the estimated values were lying within the permissible range and there were no exceptionally large or small standard errors. During CFA items having highest factor loadings were kept to make the shortened scale of each variable for conducting further analysis. Table 4.3 illustrates the factor loadings of retained items. The overall model was divided into six individual models. First model takes first independent, first mediator and the dependent variable. The second model represents first independent, second mediator and the dependent variable. Similarly third and fourth models take second independent variable, two mediators respectively and the dependent variable. The fifth and the sixth model take third independent, two mediators respectively and the dependent variable. The items in each construct having highest factor loadings were taken.

The values of GFI, CFI, RMR and RMSEA for first model were 0.904, 0.907, 0.039 and 0.160 respectively suggesting the model at good fit. The values of GFI, CFI, RMR and RMSEA for second model were $0.909,0.821,0.038$ and 0.198 respectively which represents that the model fit is good.The values of GFI, CFI, RMR and RMSEA for third model were $0.915,0.884,0.044$ and 0.220 respectively indicating good fit of the model. The values of GFI, CFI, RMR and RMSEA for fourth model were 0.949, 0.897, 0.030 and 0.157 respectively providing that the model is at good fit. The values of GFI, CFI, RMR and RMSEA for fifth model were $0.920,0.860,0.027$ and 0.163 respectively. This suggests the overall model fit as good. The values of GFI, CFI, RMR and RMSEA for the final model were $0.909,0.821,0.031$ and 0.200 respectively characterizing the overall model fit as improved. 
Table 4.3: Factor Loadings

\begin{tabular}{|l|l|l|}
\hline Variable Name & No. of Items Retained & Factor Loadings \\
\hline Workplace Bullying & 8 & $\begin{array}{l}0.81,0.87,0.78,0.77,0.78,0.88,0.78 \\
\text { and } 0.81\end{array}$ \\
\hline Workplace Incivility & 4 & $0.75,0.86,0.86$ and 0.64 \\
\hline Role Conflict & 4 & $0.81,0.85,0.63$ and 0.64 \\
\hline Role Ambiguity & 4 & $0.63,0.69,0.59$ and 0.70 \\
\hline Role Overload & 3 & $0.65,0.53$ and 0.56 \\
\hline Turnover Intention & 4 & $0.76,0.93,0.78$ and 0.91 \\
\hline
\end{tabular}

\subsubsection{Structural Model}

Later on, path model diagram was drawn and path model hypotheses were tested. Consistent withKline, (2011)all the model fit indices of structural model fell within acceptable range for the study under discussion $(\mathrm{CFI}=0.955, \mathrm{GFI}=0.957, \mathrm{RMR}=0.014$ and RMSEA=0.378). The model fit states that the results of the hypotheses postulated in the study are credible.

The hypotheses for the study were analyzed one by one and their results have been presented in the Table 4.4.At start the first hypothesis $\mathrm{H} 1$ was tested that is Role Conflict will have a positive association with Workplace Bullying among banking professionals of Pakistan. The results state that there is a significant relationship between role conflict and workplace bullying ( $\beta=0.350$ and $\mathrm{p}<0.05$ ).So $\mathrm{H} 1$ is accepted. This relationship confirms the findings of previous studies like (Einarsen et al., 1994). After that $\mathrm{H} 2$ was tested that is Role Conflict will have a positive association with Workplace Incivility among banking professionals of Pakistan. The results state that there is a significant relationship between role conflict and workplace Incivility $(\beta=0.685$ and $p<0.001)$. So $\mathrm{H} 2$ is accepted. This relationship was also found significant in the study of (Taylor and Kluemper, 2012).Afterward H3 was tested. The results affirm that there is a significant relationship between role ambiguity and workplace Bullying $(\beta=0.685$ and $p<0.001)$. So H3 is supported and accepted. Einarsen et al. (1994) found this relationship significant in a Norwegian study. Later on, H4 was tested. The results affirm that there is a significant relationship between role ambiguity and workplace Incivility ( $\beta=0.235$ and $\mathrm{p}<0.001)$. So H4 is affirmed and accepted.C. M. Pearson et al.,(2000), in their study also found this relationship significant. After that $\mathrm{H} 5$ was tested. The results assert that there is a significant relationship between role overload and workplace Bullying $(\beta=0.172$ and $\mathrm{p}<0.05$ ). So H5 is confirmed and acknowledged. Baillien et al. (2011) used Job Demand Control Model of (Karasek, 1979) and found the relationship between RO and WB significant. Next H6 was tested. The results declare that there is a significant relationship between role overload and workplace Incivility $(\beta=0.172$ and $p<0.001)$ that provides the basis for accepting H6.Pearson andPorath, (2004) found this relationship significant. Then H7 was tested that. A significant relationship between role Conflict and Turnover Intention $(\beta=0.172$ and $\mathrm{p}<0.001)$ is declared by the results which affirms that that $\mathrm{H} 7$ should be accepted. Igbaria and Siegel, (1992b) confirmed that there is a significant relationship between role conflict and turnover intention. After testing seventh hypothesis, H8 was tested. The results demonstrate that there is not statistically significant relationship between Role ambiguity andturnover intention $(\beta=0.0 .029$ and $p>0.05)$ that provides basis for not accepting H8.Hamner and Tosi, (1974) conducted research and reported that the relationship between role ambiguity and turnover intentions is not significant. Later on $\mathrm{H} 9$ was tested. The results suggest that there is a significant relationship between role overload and turnover $(\beta=0.568$ and $\mathrm{p}<0.001)$ that provides the basis for accepting H9.Hang-Yue et al.(2005) also found a significant association between role overload and turnover intention. 
This study also includes the mediating relationships, so it is important to draw results regarding mediating relationships among variables. To draw the results of these mediating relationships rules of mediation established by (Baron and Kenny, 1986) were taken as the benchmark. Keeping these rules in mind H10 was tested and it was found that Workplace Bullying partially mediates the relationship between role conflict and turnover intention.Ayoko et al.(2003) conducted a study and found similar relationship.

Further, H11 was tested and it was found that Workplace Incivility partially mediates the relationship between role conflict and turnover intention. Taylor andKluemper, (2012) also tested workplace incivility as mediator among role stressors and enacted work aggression and found that Workplace Incivility played a mediating role between these two. Moreover,workplace bullying fully mediates the relationship between role ambiguity and turnover intention which provides basis for accepting H12.Bulutlar andÖz, (2009) found similar results in a study.

Furthermore, the results indicate that workplace incivility fully mediates the relationship between role ambiguity and turnover intention thus accepting H13.Taylor andKluemper, (2012) conducted a study to test the mediating effect of workplace incivility and found similar results. Afterwards, H14 was tested. The results show that workplace bullying partially mediates the relationship between role overload and turnover intention thus validating H14. Balducci et al.(2011) found that Workplace Bullying plays a mediating role between job demands and post-traumic stress symptoms. Additionally, Workplace Incivility partially mediates the relationship between role overload and turnover intention. These results validate H15. Taylor andKluemper, (2012) also found that Workplace Incivility may be used as mediator.H16 was tested andthe results proposed that there is a significant relationship between workplace bullying and turnover intention $(\beta=0.153$ and $p<0.001)$ thus accepting H16.Naseer and Khan, (2015) found similar relationship between these two constructs in a study.Finally $\mathrm{H} 17$ was tested. The results recommend that there is a significant relationship between workplace incivility and turnover intention $(\beta=0.195$ and $\mathrm{p}<0.05)$ providing basis for accepting H17.Oyeleye et al. (2013)reported similar results in his study.

Table 4.4: Regression Weights

\begin{tabular}{|l|l|l|l|l|}
\hline Relationships & Estimate $(\boldsymbol{\beta})$ & S.E. & C.R. & P \\
\hline RC $\rightarrow$ WB & .350 & .121 & 2.894 & .004 \\
\hline RC $\rightarrow$ WInc & .685 & .070 & 9.770 & $* * *$ \\
\hline RA $\rightarrow$ WB & .638 & .079 & 8.073 & $* * *$ \\
\hline $\mathrm{RA} \rightarrow$ WInc & .235 & .046 & 5.134 & $* * *$ \\
\hline RO $\rightarrow$ WB & .172 & .076 & 2.275 & .023 \\
\hline RO $\rightarrow$ WInc & .172 & .044 & 3.925 & $* * *$ \\
\hline RC $\rightarrow$ TI & .283 & .104 & 2.734 & .006 \\
\hline RA $\rightarrow$ TI & .029 & .067 & .440 & .660 \\
\hline RO $\rightarrow$ TI & .568 & .058 & 9.877 & $* * *$ \\
\hline WB $\rightarrow$ TI & .153 & .043 & 3.577 & $* * *$ \\
\hline WInc $\rightarrow$ TI & .195 & .074 & 2.637 & .008 \\
\hline
\end{tabular}




\section{CONCLUSION,LIMITATIONS AND FUTURE RECOMMENDATIONS}

\subsection{Conclusion}

This research examines the causes and effects of workplace interpersonal mistreatment among banking professionals of Pakistan. Furthermore, this study also focused to check the mediating effects of workplace bullying and workplace incivility. This study has addressed seventeen hypotheses. The results describe the relationships among role stressors, workplace mistreatment and turnover intention among banking professionals of Pakistan. Different statistical techniques were employed to test the hypothesis against the data collected through personally administered questionnaires.

The first three hypotheses focus on the relationship of role conflict with workplace bullying, workplace incivility and turnover intention. Statistical results support hypotheses $H 1, H 2$, and H3. These results indicate that a greater role conflict will result in increased workplace bullying increased workplace, incivility and increased turnover intention. Hypotheses $H 6, H 7$ and $H 8$ focus on studying the relationship of role ambiguity with workplace bullying, workplace incivility and turnover intention. Statistical results support hypotheses $H 6$ and $H 7$ but don't support $H 8$. These results indicate that a greater role ambiguity will result in increased workplace bullying and increased workplace incivility. Hypotheses H1l, H12 and H13 attempts to establish the relationship of role overload with workplace bullying, workplace incivility and turnover intention. Statistical results support hypotheses $H 11, H 12$, and H13. These results indicate that an increase in role overload will result in increased workplace bullying increased workplace, incivility and increased turnover intention.

Hypotheses $\mathrm{H} 4, \mathrm{H} 5, \mathrm{H} 9, \mathrm{H} 1 \mathrm{O}, \mathrm{H} 14$ and $\mathrm{H} 15$ focus on testing the mediating effects of workplace bullying and workplace incivility among role stressors and turnover intention. Statistical results support hypotheses $\mathrm{H4}, \mathrm{H5}, \mathrm{H} 9, \mathrm{H1O}, \mathrm{H} 14$ and $\mathrm{H15}$. These results indicate that workplace bullying and workplace incivility partially mediates the relationship among role conflict and turnover intention, and role overload and turnover intention andfully mediate the relationship between role ambiguity and turnover intention. Set of last two hypotheses $H 16$ and $H 17$ concentrates on testing the relationship of workplace bullying and workplace incivility with turnover intention. Statistical results support hypotheses $H 16$ and H17. These results indicate that an increase in workplace bullying and workplace incivility will result in increased turnover intention among banking professionals of Pakistan

\subsection{Contribution to Knowledge}

This research was carried out in the banking sector of Pakistan where it was postulated that banking employees' turnover intentions are majorly contributed by role stressors and workplace interpersonal mistreatment. There was no previous study employing this theoretical framework. By using the current theoretical framework, the researcher has attempted to describe a causal relationship among role stressors, workplace bullying, and workplace incivility and turnover intentions. Therefore, it can be proclaimed that this research is the first attempt in taking role stressors, workplace mistreatment and turnover intention into one theoretical model. Furthermore, workplace bullying and workplace incivility have been used as mediators at the same time which has not previously been done.Another contribution of this study to knowledge is that the mediation impact of workplace bullying and workplace incivility between role stressors and turnover intentions has been checked first time. 


\subsection{Contribution to Practice}

This research has mainly focused on several organizational elements that contribute to initiating and boosting the feelings of workplace mistreatment among banking professionals of Pakistan which provide the human resource management of banking sector with important implications. With the help of modification in HR practices, numerous attempts can be made to overcome the situations of workplace mistreatment before initiation. Banking professionals have to work for longer hours. Management must take into consideration the hiring needs due to increased workload, so that the employees could manage their work properly.

When a problem is identified, it is half solved. The proposed framework helps to the management to recognize the contribution of various factors that lead to workplace mistreatment and turnover intentions.

\subsection{LimitationsandFuture Recommendations}

Even though the findings of this research are promising, yet some limitations of this study are there that could be and must be addressed in future research.The current study was crosssectional in nature thus having time limitations. The study should be repeated at different points in time. Another limitation to this study is that the data was gathered through questionnaires. Interview techniques, self-report measures and focus groups were ignored which may be an implication for future researchers. Another limitation of this study is that only two types of workplace interpersonal mistreatment that are workplace bullying and workplace incivility have been investigated in this study. Future researchers should conduct study on other types of mistreatment like harassment, emotional abuse, physical abuse ostracism etc. Non probability sampling was used in this study because of unavailability of sampling frame. A sampling frame must be devised by the future researchers so that probability sampling could be applied. Finally, this research is concerned with a national sample thus there is an issue of its generalisability in other countries because the culture and the context of different countries vary. This research should be carried out in different cultures and countries in order to replicate the results of this study. 


\section{REFERENCES}

Anderson, J. C., \& Gerbing, D. W. (1988). Structural equation modeling in practice: A review and recommended two-step approach. Psychological Bulletin, 103(3), 411.

Andersson, L. M., \& Pearson, C. M. (1999). Tit for tat? The spiraling effect of incivility in the workplace. Academy of Management Review, 24(3), 452-471.

Ayoko, O. B., Callan, V. J., \& Härtel, C. E. (2003). Workplace conflict, bullying, and counterproductive behaviors. The International Journal of Organizational Analysis, 11(4), 283-301.

Ayyub, S., Awan, A., \& Bilal, M. (2013). Interactive effect of organizational cynicism and interpersonal mistreatment on turnover intentions. In Proceedings of International Conference on Business Management \& IS (Vol. 2).

Baillien, E., De Cuyper, N., \& De Witte, H. (2011). Job autonomy and workload as antecedents of workplace bullying: A two-wave test of Karasek's Job Demand Control Model for targets and perpetrators. Journal of Occupational and Organizational Psychology, 84(1), 191-208.

Baillien, E., \& De Witte, H. (2009). Why is organizational change related to workplace bullying? Role conflict and job insecurity as mediators. Economic and Industrial Democracy, 30(3), 348-371.

Baillien, E., Neyens, I., \& De Witte, H. (2008). Organizational, team related and job related risk factors for workplace bullying, voilence and sexual harassment in the workplace: A qualitative study. International Journal of Organisational Behaviour, 13(2), 132146.

Balducci, C., Fraccaroli, F., \& Schaufeli, W. B. (2011). Workplace bullying and its relation with work characteristics, personality, and post-traumatic stress symptoms: An integrated model. Anxiety, Stress \& Coping, 24(5), 499-513.

Bibi, Z., Karim, J., \& ud Din, S. (2013). Workplace Incivility and Counterproductive Work Behavior: Moderating Role of Emotional Intelligence. Pakistan Journal of Psychological Research, 28(2).

Black, J. S. (1988). Work role transitions: A study of American expatriate managers in Japan. Journal of International Business Studies, 277-294.

Blau, G., \& Andersson, L. (2005). Testing a measure of instigated workplace incivility. Journal of Occupational and Organizational Psychology, 78(4), 595-614.

Boswell, W. R., Olson-Buchanan, J. B., \& LePine, M. A. (2004). Relations between stress and work outcomes: The role of felt challenge, job control, and psychological strain. Journal of Vocational Behavior, 64(1), 165-181.

Brief, A. P., \& Aldag, R. J. (1976). Correlates of role indices. Journal of Applied Psychology, $61(4), 468$.

Bruursema, K. (2005). Leadership style and the link with counterproductive work behavior $(C W B)$ : An investigation using the job-stress/CWB model. University of South Florida.

Bulutlar, F., \& Öz, E. Ü. (2009). The effects of ethical climates on bullying behaviour in the workplace. Journal of Business Ethics, 86(3), 273-295.

Coldwell, D. A. (1979). Role conflict, job satisfaction and situational anxiety amongst Black industrial workers. Psychologia Africana. Retrieved from http://psycnet.apa.org/psycinfo/1981-11366-001

Cortina, L. M., Magley, V. J., Williams, J. H., \& Langhout, R. D. (2001). Incivility in the workplace: incidence and impact. Journal of Occupational Health Psychology, 6(1), 64.

Dollard, J., Miller, N. E., Doob, L. W., Mowrer, O. H., \& Sears, R. R. (1939). Frustration and aggression. Retrieved from http://doi.apa.org/psycinfo/2004-16227-000 
Einarsen, S. ale, \& Hoel, H. (2001). The Negative Acts Questionnaire: Development, validation and revision of a measure of bullying at work. In 10th European congress on work and organisational psychology, Prague.

Einarsen, S. ale, \& Raknes, B. I. (1997). Harassment in the workplace and the victimization of men. Violence and Victims, 12(3), 247-263.

Einarsen, S. ale, Raknes, B. rn I., \& Matthiesen, S. B. (1994). Bullying and harassment at work and their relationships to work environment quality: An exploratory study. European Journal of Work and Organizational Psychology, 4(4), 381-401.

Einarsen, S. (1999). The nature and causes of bullying at work. International Journal of Manpower, 20(1/2), 16-27. http://doi.org/10.1108/01437729910268588

Einarsen, S., Hoel, H., \& Cooper, C. (2003). Bullying and emotional abuse in the workplace: International perspectives in research and practice. CRC Press.

Floyd, F. J., \& Widaman, K. (1995). Factor analysis in the development and refinement of clinical assessment instruments. Psychological Assessment, 7(3), 286.

French, J. R., \& Caplan, R. D. (1972). Organizational stress and individual strain. The Failure of Success, 30, 66.

French, J. R., Caplan, R. D., \& Van Harrison, R. (1982). The mechanisms of job stress and strain (Vol. 7). Chichester [Sussex]; New York: J. Wiley.

Futrell, C. M., \& Parasuraman, A. (1981). Impact of clarity of goals and role perceptions on job satisfaction. Perceptual and Motor Skills, 52(1), 27-32.

Glomb, T. M., Richman, W. L., Hulin, C. L., Drasgow, F., Schneider, K. T., \& Fitzgerald, L. F. (1997). Ambient sexual harassment: An integrated model of antecedents and consequences. Organizational Behavior and Human Decision Processes, 71(3), 309328.

Graen, G. (1976). Role-making processes within complex organizations. Handbook of Industrial and Organizational Psychology. Chicago: Rand McNally, 1245.

Hair, J. F., Black, W. C., Babin, B. J., Anderson, E., \& Tatham, R. (2006). Multivariate data analysis (Vol. 6). Pearson Prentice Hall Upper Saddle River, NJ.

Hamner, W. C., \& Tosi, H. L. (1974). Relationship of role conflict and role ambiguity to job involvement measures. Journal of Applied Psychology, 59(4), 497.

Hang-Yue, N., Foley, S., \& Loi, R. (2005). Work role stressors and turnover intentions: a study of professional clergy in Hong Kong. The International Journal of Human Resource Management, 16(11), 2133-2146.

Hoel, H., \& Salin, D. (2003). 10 Organisational antecedents of workplace bullying. Bullying and Emotional Abuse in the Workplace, 203.

Ivancevich, J. M., \& Donnelly, J. H. (1974). A study of role clarity and need for clarity for three occupational groups. Academy of Management Journal, 17(1), 28-36.

Johnson, P. R., \& Indvik, J. (2001). Slings and arrows of rudeness: Incivility in the workplace. Journal of Management Development, 20(8), 705-714.

Jones, E., Chonko, L., Rangarajan, D., \& Roberts, J. (2007). The role of overload on job attitudes, turnover intentions, and salesperson performance. Journal of Business Research, 60(7), 663-671.

Kahn, R. L., Wolfe, D. M., Quinn, R. P., Snoek, J. D., \& Rosenthal, R. A. (1964). Organizational stress: Studies in role conflict and ambiguity.

Kamp, J., \& Brooks, P. (1991). Perceived organizational climate and employee counterproductivity. Journal of Business and Psychology, 5(4), 447-458.

Keashly, L., \& Jagatic, K. (2000). The nature, extent and impact of emotional abuse in the workplace: Results of a statewide survey. In Presentado en el Annual Meeting of the Academy of Management, Toronto, Ontario, Canada. 
Keenan, A., \& McBain, G. D. M. (1979). Effects of Type A behaviour, intolerance of ambiguity, and locus of control on the relationship between role stress and workrelated outcomes. Journal of Occupational Psychology, 52(4), 277-285.

Kelloway, E. K., Gottlieb, B. H., \& Barham, L. (1999). The source, nature, and direction of work and family conflict: a longitudinal investigation. Journal of Occupational Health Psychology, 4(4), 337.

Kivimäki, M., Elovainio, M., \& Vahtera, J. (2000). Workplace bullying and sickness absence in hospital staff. Occupational and Environmental Medicine, 57(10), 656-660.

Kline, R. B. (2011). Principles and Practice of Structural Equation Modeling, 3rd edn Guilford Press. New York.

Lawrence, C. (2001). Social psychology of bullying in the workplace. Building a Culture of Respect: Managing Bullying at Work, 61-76.

Longo, J., \& Sherman, R. O. (2007). Leveling horizontal violence. Nursing Management, 38(3), 34-37.

Lyons, T. F. (1971). Role clarity, need for clarity, satisfaction, tension, and withdrawal. Organizational Behavior and Human Performance, 6(1), 99-110.

Malik, M. I., Sajjad, M., Hyder, S., Ahmad, M. S., Ahmed, J., \& Hussain, S. (2013). Role Overload: A Cause of Diminishing Employee Retention and Productivity. MiddleEast Journal of Scientific Research, 18(11), 1573-1577.

Mata, L. S. (2012). Understanding Workplace Bullying. AuthorHouse.

Milam, A. (2013). Chapter seven workplace incivility in pakistani organizations: an indigenous perspective rubinahanif1. In Psychology at Work in Asia: Proceeds of the 3rd and 4th Asian Psychological Association Conferences and the 4th International Conference on Organizational Psychology (p. 82). Cambridge Scholars Publishing.

Miles, R. H. (1974). Role conflict and ambiguity in boundary and internal roles: a field study using role-set analysis and a panel design.

Mount, M., Ilies, R., \& Johnson, E. (2006). Relationship of personality traits and counterproductive work behaviors: The mediating effects of job satisfaction. Personnel Psychology, 59(3), 591-622.

Naimon, E. C., Mullins, M. E., \& Osatuke, K. (2013). The effects of personality and spirituality on workplace incivility perceptions. Journal of Management, Spirituality \& Religion, 10(1), 91-110.

Naseer, S., \& Khan, M. B. (2015). The Deleterious Effects of Workplace Bullying on Employee's Job Strains in Pakistan. European Journal of Business and Management, 7(4), 180-190.

Nunnally, J. C., \& Bernstein, I. H. (1994). The assessment of reliability. Psychometric Theory, 3, 248-292.

Organ, D. W., \& Greene, C. N. (1974). Role ambiguity, locus of control, and work satisfaction. Journal of Applied Psychology, 59(1), 101.

Oyeleye, O., Hanson, P., O'Connor, N., \& Dunn, D. (2013). Relationship of workplace incivility, stress, and burnout on nurses' turnover intentions and psychological empowerment. Journal of Nursing Administration, 43(10), 536-542.

Pallant, J. (2007). SPSS survival manual: A step-by-step guide to data analysis using SPSS version 15. Maidenhead, Berkshire, England: McGraw-Hill Education.

Parasuraman, S. (1982). Predicting turnover intentions and turnover behavior: A multivariate analysis. Journal of Vocational Behavior, 21(1), 111-121.

Pearson, C. M., Andersson, L. M., \& Porath, C. L. (2000). Assessing and attacking workplace incivility. Organizational Dynamics, 29(2), 123-137.

Pearson, C. M., \& Porath, C. L. (2004). On incivility, its impact, and directions for future research. The Dark Side of Organizational Behavior, 16, 403. 
Pearson, C. M., \& Porath, C. L. (2005). On the nature, consequences and remedies of workplace incivility: No time for "nice"? Think again. The Academy of Management Executive, 19(1), 7-18.

Rizzo, J. R., House, R. J., \& Lirtzman, S. I. (1970a). Role conflict and ambiguity in complex organizations. Administrative Science Quarterly, 150-163.

Rizzo, J. R., House, R. J., \& Lirtzman, S. I. (1970b). Role conflict and ambiguity in complex organizations. Administrative Science Quarterly, 150-163.

Sager, J. K., Griffeth, R. W., \& Hom, P. W. (1998). A comparison of structural models representing turnover cognitions. Journal of Vocational Behavior, 53(2), 254-273.

Schuler, R. S. (1977). Role conflict and ambiguity as a function of the task-structuretechnology interaction. Organizational Behavior and Human Performance, 20(1), 6674.

Skogstad, A., Einarsen, S. ale, Torsheim, T., Aasland, M. S., \& Hetland, H. (2007). The destructiveness of laissez-faire leadership behavior. Journal of Occupational Health Psychology, 12(1), 80.

Tabachnick, B. G., Fidell, L. S., \& others. (2001). Using multivariate statistics.

Taylor, S. G., \& Kluemper, D. H. (2012). Linking perceptions of role stress and incivility to workplace aggression: the moderating role of personality. Journal of Occupational Health Psychology, 17(3), 316.

Tett, R. P., \& Meyer, J. P. (1993). Job satisfaction, organizational commitment, turnover intention, and turnover: path analyses based on meta-analytic findings. Personnel Psychology, 46(2), 259-293.

Tosi, H., \& Tosi, D. (1970). Some correlates of role conflict and role ambiguity among public school teachers. Journal of Human Relations, 18(3), 1068-1076.

Waldman, J. D., Kelly, F., Aurora, S., \& Smith, H. L. (2004). The shocking cost of turnover in health care. Health Care Management Review, 29(1), 2-7. 